\title{
The Cascading Helix. A three-dimensional conceptual model aimed at improving organizational communication and performance
}

\author{
J. Raddall
}

Pretoria

\begin{abstract}
This article introduces the Cascading Helix as a threedimensional dynamic, conceptual model which represents formal and informal relationships in an organization. The Helix replaces the traditional two-dimensional static model which has been used for decades. It is suggested that this latter model has become inadequate to represent real world conditions that exist in the eighties. The Helix can be used by companies as a practical model. Employees' names can be attached hierarchically to the Helix which can move from steady state to inversion and back to steady state. This dynamic process introduces an important concept, i.e. the benefits of shared strategic responsibility. Strategic decision-making is not the sole domain of top management. Each employee has a contribution to make in determining the direction of the company. Certain topics, important to a firm's survival are also discussed. These include infor. mal communication, values and culture, organizational control, conflict resolution and strategic management. In this article it is suggested that the Cascading Helix can be used as an educational tool in these areas to bring about necessary changes in the organization's philosophy and behaviour.

S. Afr. J. Bus. Mgmt. 1984, 15: 232-236
\end{abstract}

Hierdie artikel stel die Dinamiese Spiraal (Cascading Helix) as 'n driedimensionele dinamiese begripsmodel bekend, wat formele en informele verhoudings binne 'n organisasie verteenwoordig. Die spiraal vervang die tweedimensionele, statiese model wat al vir dekades in gebruik is. Dit blyk dat die model nie langer werklike wêreldtoestande van die tagtigerjare weerspieèl nie. Maatskappye kan die spiraal as 'n praktiese model gebruik. Werknemers se name kan hiërargies aan die spiraal gekoppel word, en die spiraal kan beweeg van 'n stabiele staat tot die omgekeerde, en weer terug na stabiel. Die dinamiese proses stel 'n belangrike begrip bekend, naamlik die voordele van gemeen. skaplike strategiese verantwoordelikheid. Die topstruktuur het nie meer alleenreg op strategiese besluitneming nie. Elke werk. nemer kan 'n bydrae lewer tot die bepaling van die rigting van die maatskappy. Sekere onderwerpe wat belangrik is vir 'n maatskappy se voortbestaan word ook bespreek. Dit sluit informele kommunikasie, waardes en kultuur, organisatoriese beheer, konflikoplossing en strategiese bestuur in. In hierdie artikel word daar voorgestel dat die dinamiese spiraal gebruik kan word as opleidingswerktuig op hierdie gebiede, om die nodige veranderinge in die organisasie se beleid en optrede te bewerkstellig. S.Afr. Tydskr. Bedryfsl. 1984, 15: 232-236

\section{J. Raddall}

c/o Council for Scientific and Industrial Research, P.O. Box 395,

Pretoria, 0001 Republic of South Africa

Received September 1984

\section{Introduction}

The intellectual capacity of every human being is made up of a unique and complex interaction of many variables, composed of both genetic and environmental factors. As a result people tend to perceive issues differently, leading to a wide spectrum of intellectual, emotional and physical behaviour.

In every avenue of human endeavour coping mechanisms have been developed to control the variety naturally inherent in Homo sapiens and his environment, e.g. the discipline taught in schools and the army, driving on the left hand side of the road, and working from eight to five.

Much has been written during the last 20 years (Koestler, Toffler, Nesbitt) about our environment and its trend towards greater turbulance and change and the effect this will have on organizations.

Naturally this evolution has led to a greater proliferation of variety (Beer, 1979:32) with a concomitant increase in demand for organizations to correctly amplify and attenuate the higher and more varied environmental-stimuli count in order to survive and grow.

\section{Objective}

The Cascading Helix has been developed as a conceptual model to provide organizations with a new coping mechanism in a changing milieu.

The model is simple, three dimensional and dynamic and should allow all employees to relate to it with ease, regardless of differing genetic or environmental factors.

The Cascading Helix therefore provides a common language as a starting point whereby all unwanted variety which may be present with the written or spoken word is effectively attenuated.

The model is further intended to be used as a facilitator for implementing new concepts within the organization on an ongoing basis.

\section{The traditional model}

The conventional organizational hierarchy model is depicted in Figure 1.

Traditional theory also classifies decision-making into three basic levels (Schutte, 1981:12), namely strategic, management planning and control, and operational.

The view is held in this article that the conventional model is inadequate in that it takes no account of the dynamic nature of the environment and the complexities of human interaction. 


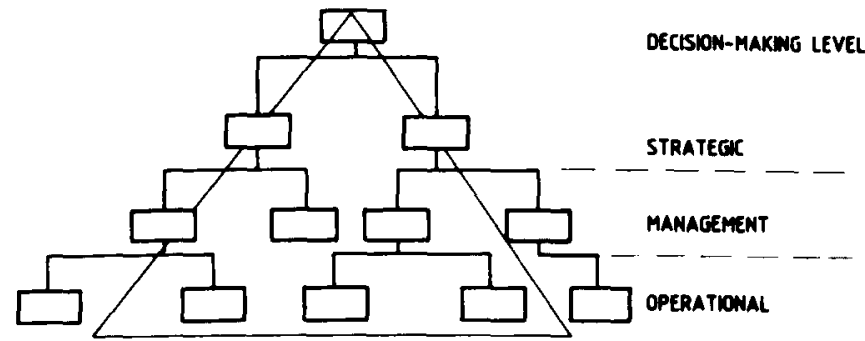

Figure 1 Traditional two-dimensional organizational hierarchy.

\section{Proposed conceptual model}

Figure 2 shows the proposed Cascading Helix model.

The Helix operates within and is controlled by a cylinder called the Organizational Control Cylinder which represents the organizational value or belief system (discussed later).

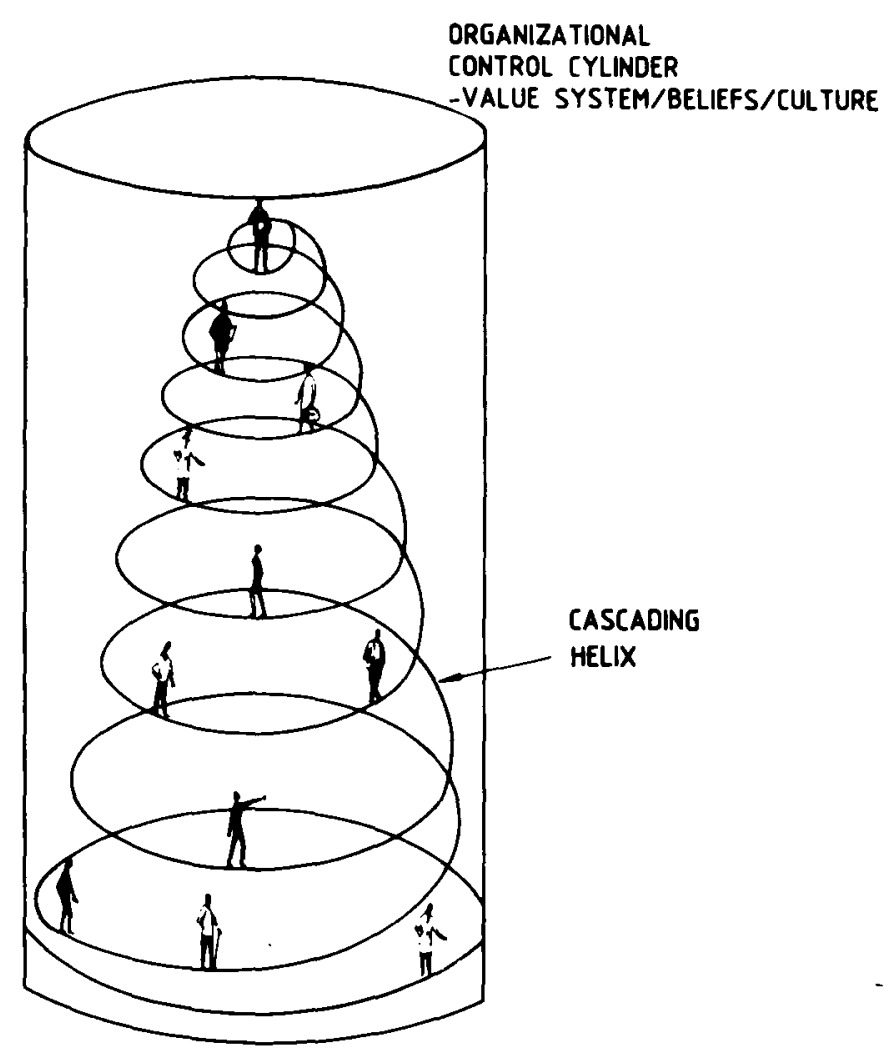

Figure 2 The Cascading Helix model.

The Helix evolved from and can be compared to the traditional model (Figure 1). In this case the employees are 'fixed' to a spiralling helix instead of to a static tree.

The first step in the evolution of the Helix was to introduce a third dimension to reflect more realistically the real world in which people operate. This is shown diagrammatically in Figure 3.

The second and most important step was to introduce movement as the dynamic component of the model (Figure 4). (Again to more closely reflect the real world).

One cycle of the Helix is from steady state to inversion and back to steady state.

An important principle when considering a dynamic alternative like the Cascading Helix is to maintain discipline through a recognized and accepted process of decisionmaking and responsibility allocation.

In this respect the Helix is exactly the same as the
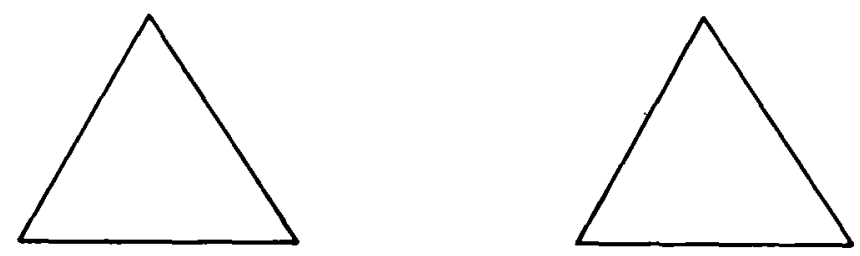

\section{ELEVATION}

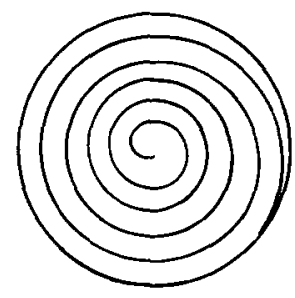

\section{PLAN}

Figure 3 Three-dimensional Helix compared with two-dimensional conventional model.
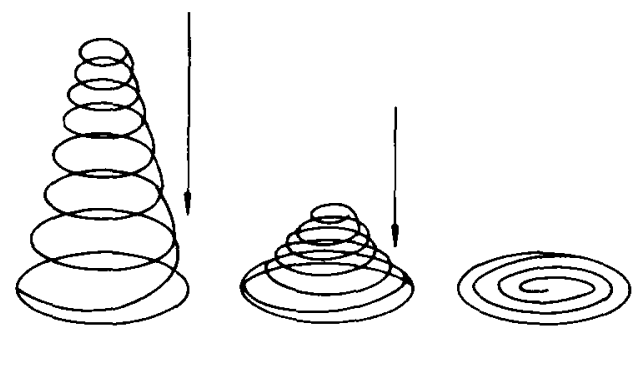

MNERSION

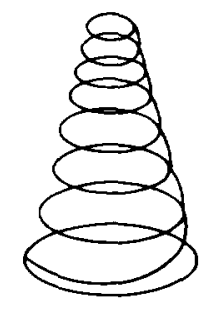

STEAOY STATE

Figure 4 Helix cycle.

traditional model. Decision-making responsibility remains hierarchical. Conceptually this is best reflected when the Helix is in a steady state.

\section{The Helix control cylinder}

This is an additional concept which may be useful to top management in organizations. The cylinder represents the organizational value system or culture. Successful companies like IBM, Hewlett Packard, Procter and Gamble, and Morgen Guaranty Trust all exhibit strong cultures. When new employees join these companies they are put through a socialization process whereby they are exposed to the companies' values and beliefs.

Many consultants believe this value system to be the basic tenet of all organizational performance. (Pascale - 'The Art of Japanese Management'; Peters and Waterman - 'In Search of Excellence'; Kanter - 'The Change Masters').

IBM for example attribute their success to close adherence to their basic philosophy of (i) concern for employees; (ii) concern for customers; and (iii) constantly striving for excellence.

For a company which produces high-technology products it is interesting to note that it is human values which provide the driving force 
Conceptually, therefore, top management should view the control cylinder (value system) as an integral part of the Helix model.

\section{Use of the Helix}

The first step for an organization is to create its own threedimensional model and attach names to the Helix.

This is considered a key step for practical application. It is far easier for employees at all levels of the organization, regardiess of language or cultural background to understand the concept of being a part of the organizational whole if they can see for themselves where they fit in on a physical model.

One manager who makes use of the Helix has split his division into sections (Figure 5).

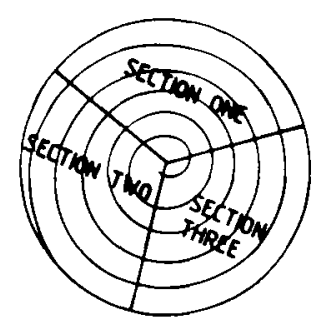

Figure 5 Helix on plan.

The name of each individual is then added to the Helix which now represents the organization (or division or group).

A further advantage of the Helix is that each individual sees himself as a part of a whole (the Helix being continuous) rather than a single unit in a collection of parts.

When the Helix is at rest in its steady state the levels of authority will be clear for all employees to see.

However, when the model is operated, i.e. the Helix goes through a cycle (steady state-inversion-steady state), employees will observe a dynamic situation where, for example, people who are normally at a higher level in the organizational hierarchy are now temporarily at the same or a lower level.

\section{Cascading Helix cycle}

Two things occur within the organization during the cycle.

(i) As the Helix tends to inversion the different management and employee levels are brought into the same plane, albeit temporarily. This is to facilitate informal communication at a horizontal level, for example between a manager and an employee.

(ii) The second point concerns environmental stimuli. Stemming from the discussion on an increasing rate of change in the environment it is clear that many companies are facing environments which are becoming ever more complex and dynamic. In other words the variety which is relevant to the company is increasing.

These changing circumstances will make it more difficult for environmental inputs to pass effectively into the company via the traditional route of top down. (Refer to Figure 1).

In a more complex environment, individual employees tend to become more specialized and to have more direct contact with outsiders such as customers, suppliers, or clients. This means that in some cases it is the employees and not the managers who may have key information needed for strategic planning. The Cascading Helix allows for this in its cycle (Figure 6).

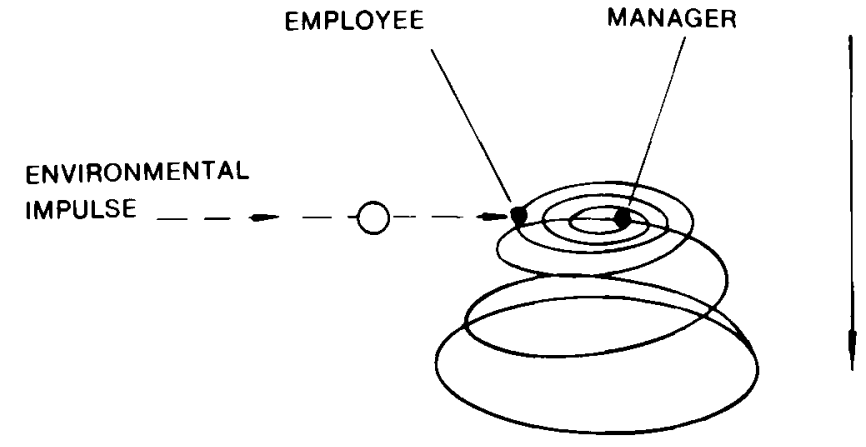

Figure 6 Helix cycle and environmental input stimulus.

Here relevant information reaches the organization via the employee before it reaches the manager. Because the employee and manager are at the same plane within the Helix cycle the former now has the responsibility to pass on this information to the manager.

This is a core concept which differs from conventional thinking. Some potential strategic responsibility has been added to all levels within the organization.

This responsibility passes to all employees automatically as the Helix moves towards inversion whereby senior personnel pass downwards on the inside of more junior personnel.

The purpose of this concept is to provide a visual framework for improving communication within an organization, the importance of which is discussed below.

\section{Important characteristics of communication}

Peters and Waterman have highlighted the following ingredients which they consider important to communication in successful companies (Peters \& Waterman, 1982:218).

(i) Communication systems are informal. They found that in excellent companies informal communication is actively encouraged. Proponents of successful ideas work primarily through the informal rather than the formal organization.

(ii) Communication intensity is extraordinary. The objective is to achieve a free-flow of ideas at all levels. A senior HP manager said, 'We're really not sure exactly how the innovative process works. But there's one thing we do know: the easy communications, the absence of barriers to talking to one another are essential. Whatever we do, whatever structure we adopt, whatever systems we try, that's the cornerstone - we won't do anything to jeopardise it'.

Intel executives have called this process 'decision-making by peers' an open, confrontation-oriented management style.

(iii) Communication is given physical support. This is done in the form of liberally distributed blackboards, or butcher paper on stands. People often need to draw or write something to explain a point and such physical trappings are seen as a spur to the intense, informal communication that underpins regular innovation.

Use can also be made of tea and lunch breaks. If the company cafeteria is well designed it will encourage informal communication between as many people as possible. The thing to be avoided is the same small groups forming every day in their own corner. The chances of sharing knowledge, ideas and values are slight indeed. This type of variety destruction is certainly not desirable. A further factor concerns the effect of location and proximity, on communication (Figure 7). 


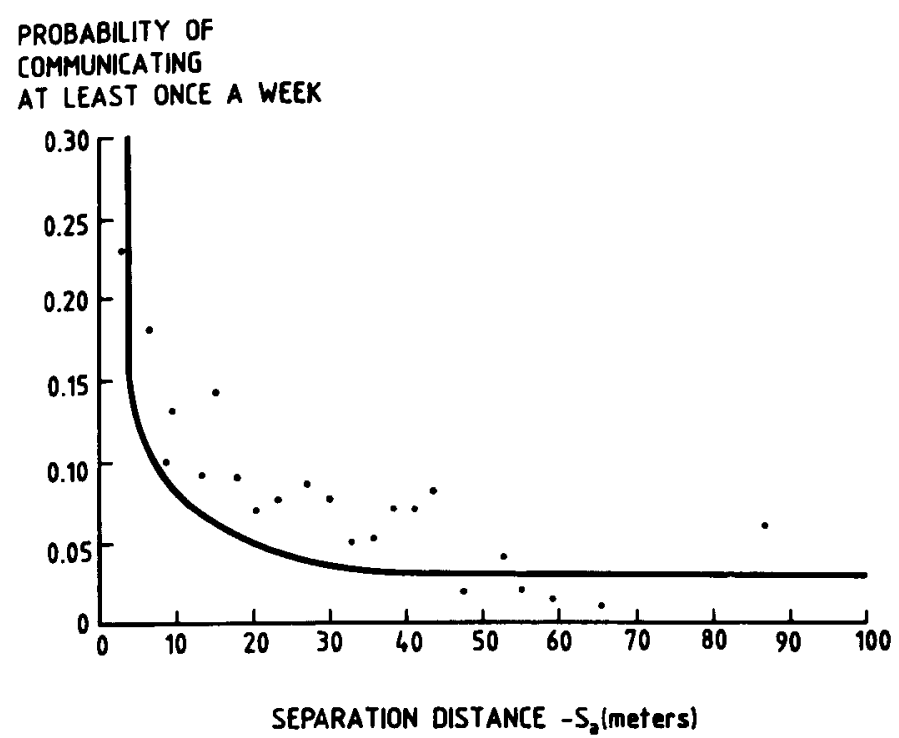

Figure 7 Effect of location on communication (Peters \& Waterman, 1982:221) ( $R$ \& $D$ and engineering laboratories).

(iv) Forcing devices. These are free-thinking agents who move within the company totally unfettered. At IBM there are about fourty-five of them, 'dreamers, heretics, gadflies, mavericks and geniuses'.

Their purpose is to shake up the system when it is moving into a dead-end and to stimulate innovation where possible

(v) The intense, informal communication system acts as a remarkably tight control system. In terms of earlier discussion it tends to balance variety attenuation and variety amplification. Again it is shared knowledge, a result of intense communication that acts as a control.

\section{Practical application of model}

\section{Informal communication}

Assuming that management agrees that communication within an organization can be improved and that informal communication is an important control mechanism, the Cascading Helix can provide the conceptual framework for understanding and developing the necessary organizational philosophy and behavioural guidelines.

This would mean developing a physical three-dimensional Cascading Helix for the organization where the names of all employees are attached in hierarchical order. Management would then use the model to explain such concepts as informal communication and strategic responsibility.

Precise practical applications will naturally vary with circumstances for each organization, but the principle or philosophy underlying the model will not vary, i.e. employees are expected to communicate with each other and at all levels within the organization as much as is necessary to maximize organizational performance.

Examples of applying the model include 'Open door' policies, quality circles, brainstorming sessions, physical office layout, informal social events and peer group comparison and discussion.

The purpose of the Cascading Helix model in this case is very much as an educational tool in explaining to all employees, not just to management, the principle of informal communication and its importance to organizational productivity. Once this is understood, practical suggestions should evolve from within the organization.

\section{Organizational focus and control}

Kanter (1983) has found a fundamental difference between successful and unsuccessful organizations which relates to the manner in which intra-organizational communication is conducted.

Unsuccessful companies were found to be highly segmented into separate and autonomous divisions. Communication between these divisions was minimal and the overall effect was slow and inadequate organizational response to environmental changes.

The successful organizations on the other hand encouraged and maintained far higher levels of informal communication between all divisions and departments, resulting in a more flexible and effective decision-making process.

Assume that a given company accepts the above findings. The Cascading Helix can now provide a conceptual thread that can unite a potentially diverse organization.

For example, R \& D, Sales, Production, and Admin, are often cited as four virtually autonomous bodies within a given organization with each group knowing very little about the activities of the next.

To improve this the organization can start by producing a Cascading Helix model divided into four sections as described above with only the key decision-making personnel from each section placed on the Helix. In this way their roles within the organization as a whole can be emphasized together with the way in which they are expected to communicate. At the same time there will be a de-emphasis on segmented or independent behaviour.

\section{Conflict resolution}

Conflict between individuals and groups in an organization appears to be a by-product of organizational activity, and there can be many causes, e.g. competition, differing personalities and values, inadequate standards set for employees by management, inadequate communication and understanding between individuals.

Unfortunately when conflict does arise attitudes can become defensive, irrational and even aggressive and unless the organization has a sound coping-mechanism, conflict can remain unresolved and become counter-productive.

A recent case concerned a senior manager and two of his employees, $A$ and $B$ A was older and more experienced, but $B$ had a higher professional qualification. The situation soon arose where $A$ became reluctant to accept authority from $B$.

The problem for the manager was to find a common platform to resolve the conflict. (He had only become aware of the conflict via a third party.)

The manager now called for an informal meeting between himself and $A$ and $B$. He deliberately chose a round table approach and then using an actual 3-dimensional Cascading Helix showed each individual his position in the organization with regard to responsibility and authority.

He then collapsed the Helix, to its inverted state, and emphasized to $A$ and $B$ that the discussion was to be conducted on a one-to-one basis i.e. while the Helix was collapsed no one of the three had authority over the other two; discussion was to be open and frank.

Having set the stage the manager then raised the issue of the personal conflict between $A$ and $B$ emphasizing the potential counter-productivity that could result from such conflict from an organizational point of view (with visual reference again to the Helix).

The ensuing discussion lead to greater understanding be- 
tween $A$ and $B$ and effectively defused the tension.

On analysing this case the manager has done the following:

(i) Established a common language (the Helix) extraneous to the feelings and personalities of $A$ and $B$. They could relate to the model without feeling threatened.

(ii) Established the rules of the game once again using the model, by showing relative positions of authority, i.e. $B$ was higher than $A$ on the Helix and both $A$ and $B$ were below the manager.

(iii) Started the game by temporarily removing authority from the discussion. This could have been difficult to do verbally but with the model this was less complicated. The visual presence of the inverted Helix was a constant reminder.

(iv) Ended by concluding the discussion and emphasizing the importance of organizational goals over personal goals. The Helix was returned at the same time to its steady state as a visual cue.

\section{Strategic management}

In its simplest terms strategic management can be defined as an ongoing process of planning and re-planning. Ideally an organization needs a self-regulating system whereby adjustment to environmental changes occurs automatically. This is shown in Figure 8.

The purpose of a self-regulating system is stability, i.e that which an organization requires to ensure survival.

At the organizational level this means there must be an ongoing process of amplifying relevant information and attenuating irrelevant information.

In larger companies top management can never hope to act as a filter to all incoming stimuli. This means that some strategic responsibility must pass to employees.

For example a machine operator may realize his equipment

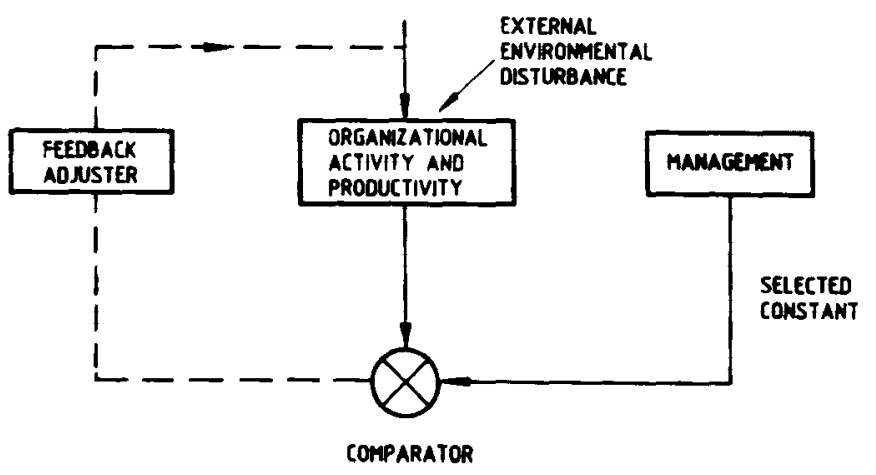

Figure 8 Self-regulating system (adapted from Beer, 1979). could be more efficient if a certain design change were made. However, if the company culture is formal and hierarchical top management is unlikely to learn of this idea, and the company will continue to be less efficient as a result.

A further example could be a company salesman. This person probably has maximum exposure to clients and potential clients and their specific needs. $\mathrm{He}$ is in an ideal position to develop ideas on product development.

Again in the absence of an adequate self-regulating system these suggestions may remain forever dormant, resulting in a degree of (avoidable) organizational instability.

At a practical level, therefore, to achieve the required selfregulating system, a company needs:

(i) effective informal communication between employees; and

(ii) a method of filtering and amplifying the relevant information.

It is suggested once more that the Cascading Helix can provide an ideal conceptual model for bringing about

(i) an organizational understanding of the relevant components in strategic management; and

(ii) provide an ongoing reference point to ensure that meaningful change is made and maintained through a process of planning and re-planning.

\section{Conclusion}

This article has introduced a conceptual model, the Cascading Helix. The model, which represents an organizational hierarchy, is three-dimensional and contains a dynamic component. The purpose of the model is to provide organizations with a sound conceptual base or common language which can be understood by employees at all levels. Certain important topics were discussed, namely informal communication, values and culture, organizational control, conflict resolution and strategic management and it was suggested that the Cascading Helix could provide a sound educational tool in bringing about change in these areas to an organization's philosophy and behaviour. The purpose of such change would be greater organizational productivity and effectiveness.

\section{References}

Beer, S. 1979. The Heart of the Enterprise. Chichester: John Wiley and Sons Ltd., 32.

Schutte, F.G. 1981. Integrated Management Systems. Butterworth and Co., (SA) (Pty) Ltd., 12.

Peters, T.J. \& Waterman, R.H. 1982. In Search of Excellence. New York: Harper and Row, 218.

Kanter, R.M. The Change Masters. New York: Simon and Schuster, 1983. 